\title{
Teaching lawyer intercultural professional communication during the COVID-19 pandemic
}

\author{
Darya Viktorovna Aleynikova
}

DOI: 10.18355/XL.2021.14.01.14

\begin{abstract}
COVID-19 Pandemic has significantly affected and changed many spheres of life. Education is said to be one of the most vulnerable. The article offers an analysis of problems faced by teachers and students during the COVID-19 Pandemic in the area of intercultural professional communication. The article provides a comparative analysis of the notions of distance teaching, online teaching, and emergent remote teaching. The author discusses problems of emergent remote teaching lawyers intercultural professional communication. One possible solution to the problems discussed is seen in the use of information and communication technology (ICT). Particular emphasis is made on the description of new ICT techniques that could be used while teaching lawyers. The author stresses the significance of continuous learning in the period of the COVID-19 Pandemic, as well as the importance of applying an action-oriented approach in teaching lawyers. The author concludes that, on the one hand, emergency remote teaching has revealed vulnerabilities. On the other hand, it has demonstrated teachers' and staff's organization skills, ability to adapt to new conditions, and creativity that boost students' motivation in the educational process. The idea of the university educational environment is the upbringing of an independent, critically thinking personality, ready to consciously build his own life, to raise his spiritual, moral, and professional level. The author regards the situation that higher education faced as a good experience. Technological advances in the informatization of education open up new prospects for increasing the availability, efficiency, and quality of education. The author employs an experimental research design and combines both qualitative and quantitative design: descriptive and statistical analyses (correlation analysis and T-test).
\end{abstract}

Key words: remote teaching, intercultural professional communication, COVID-19 Pandemic, modern lawyer professional formation, information and communication technology

\section{Introduction}

The COVID-19 crisis has put the whole society in the conditions unknown before. It has touched every sphere of our life, bringing significant changes. Education is not an exception. The closure of universities and other educational institutions affected more than 500 million students worldwide. Subsequently, the Russian Federation's Government suspended face-to-face teaching and established measures to maintain remote education within the period of the COVID-19 Pandemic. Nevertheless, such an immediate turn from a traditional form of studying to studying online proved to be challenging for teachers and students. As such, it is crucial to realize that teachers were vulnerable in such circumstances and, at the same time, eager to provide a high level of teaching in a new reality. McQuirter (2020) highlights that educators met a wide range of challenges but at the same time brought positive changes in moving to online learning. The survey conducted in a Pioneer Caribbean Dental School considering teachers' and students' perception of the effectiveness of emergent teaching points to the fact that teachers found such a rapid transition quite difficult, but at the same time most teachers mentioned that they successfully "created an enthusiastic online environment" (Rafeel et al., 2020). 
Online-learning in teaching languages is not regarded as new. It appeared in the first half of the 20th century. Many universities have introduced courses in legal English and other subjects. The educational software was created specifically for such purposes. Online learning considers such an organization of the educational process in which teachers have developed a curriculum mainly based on self-study. Onlinelearning supposes that students and teachers are separated in space and/or time, but they can carry out a dialogue via the internet. The whole educational process is based on a set system that includes a list of submitted tasks at an educational virtual platform and classes delivered at various educational platforms known as Virtual Learning Environment (VLE). At Moscow State Linguistic University, we apply SKYPE, Moodle, Zoom, Google Meet, etc.

The critical point is that there is a significant distinction between well-planned online courses and emergency remote teaching (Hodges et al. 2020). It takes about 6-9 months to prepare a high-quality online system and proves to the point how challenging it was to get accustomed to new circumstances within a limited time period. Teachers had to start thinking unconventionally to work out literally a new strategy of teaching common things from a different perspective. That is what we did, trying to face strongly the perspectives brought by COVID-19.

The scope of our teaching deals with teaching lawyers intercultural professional communication. Nowadays, teaching lawyers intercultural professional communication aims not only to increase the initial level of language proficiency but also to prepare competitive specialists ready and willing to work in the intercultural dimensions. We could achieve the aim by integrated use of intercultural, contextual, personality-oriented, and discursive approaches in teaching intercultural professional communication. The fact that we were to get accustomed to remote-learning proved that it is time we analyzed and rethought the educational process regarding new demands. These flagrant perceptions provided the intrinsic motivation for this research.

\subsection{Aim of the Study}

In connection with what has been said, it should be noted that COVID-19 created new conditions in teaching worldwide. The Russian Federation switched to emergent remote teaching on the 16th of March 2020. There has been a widespread and unforeseen infiltration of modern technologies in teaching lawyers intercultural professional communication.

Subsequently, this study intends to examine innovative methods of remote teaching lawyers intercultural professional communication and the influence of emergent online teaching on its quality.

The following research questions guided the study:

- What are some challenges of emergent remote teaching lawyers intercultural professional communication?

-What technological tools were introduced in the studying process?

- What is the influence of the introduced instruments?

\section{Literature overview}

\subsection{Analysis of scientific and pedagogical literature}

The analysis of the literature and Internet resources on this topic showed that teaching online is well-studied, and it considers several notions that may give rise to misunderstandings. In order to avoid any ambiguity, we are going to explore the idea that is behind these notions.

Concerning computer technologies/ICT, scholars distinguish e-learning, distance learning, remote learning, and blended/virtual/hybrid learning. 
Federal Law of the Russian Federation about Education in the Russian Federation (2012) draws a distinction between "e-learning" and "distance learning." According to article 16 of the law mentioned above, "e-learning is understood as the organization of educational process with the application and implementation of the information provided in databases, educational programs, and information technologies, as well as with the use of telecommunication networks that provide information transmission over the communication lines, the interaction between students and teaching staff." Whereas "distance learning technologies are understood as educational technologies implemented mainly with the use of information and communication networks in the indirect interaction of students and teachers" (Federal law, 2012). It has been suggested that for e-learning, it is obligatory to apply electronic educational resources in any e-learning system (database), and teaching at a distance without using a virtual learning environment is defined as distance learning.

It is necessary to note that the ideas of distance learning are not fundamentally new in pedagogy. Polat et al. (2008), Andreev (1998), Klarin (2016), Khutorskoi (2000) studied the distance-learning approach. According to the authors, the distance learning process involves the use of the developed system in the joint activities of teacher and students with the application of electronic educational resources. Polat (2000) notes that distance learning is a relatively new form of learning that is to be based on the fundamental didactic principles (conscious approach, activity, individualization, visualization, differentiated and integrated instruction, accessibility, durability). Nevertheless, they are to be introduced with regard to new conditions of the educational process.

Khutorskoi (2000) pays great attention to the necessity of the development of the basics of distance education. Among the essential areas of scientific research the author defines: "philosophy, methodology, the psychology of virtual education; the basic curriculum, providing for asynchronous forms of education and the combine full-time and distance learning; electronic textbooks, web quests, educational sites; telecommunication educational technologies that provide distributed education; systems for remote diagnostics, monitoring, and certification, testing, document management, personnel training, restructuring of the advanced training system transition from full-time courses to the use of Internet technologies for professional self-improvement." It is highly likely that all these areas were thoroughly examined, and the experience was incorporated in everyday distance education. The opposite is the situation considering emergency remote learning, in which necessary resources, professional staff, student accessibility were to be organized under tight deadlines.

Modern researchers and pedagogists are widely exploring the extremely created reality of teaching online. They point out that emergency remote teaching revealed a range of vulnerabilities of the educational systems worldwide. According to Cherdakli (2020), most of the teachers have a reasonably high level in the field of information and communication technologies. However, the experience of introducing emergency distance learning based on computer telecommunications shows that Russian teachers, who are professionals in the subject area, at the same time lack knowledge in the field of information technology.

On the other hand, we should not forget about the students' motivation. Students can lose their motivation due to many reasons. Some are distracted by the media, while others find that the university's working atmosphere is totally lost. We can confirm that we faced psychological difficulties involving some of the students in the educational process carried out in a new format. These psychological difficulties might have affected the effectiveness of the studies and the result. The lack of face-toface interaction with the teacher and technical communication interferences also reduced the students' motivation to participate in the learning process actively. A decrease in motivation is observed among students who were not active enough in the full-time study process. The absence of face-to-face interaction, often arising 
technical problems of Internet communication, led students with a low level of selfcontrol and self-organization to an irrelevant attitude to the learning process. A student with a low level of motivation cannot develop the competencies necessary for him as a professional in the chosen area (Tantsura, 2020).

\subsection{Analysis of foreign scientific and pedagogical literature}

Foreign studies show reliable experience in the field of distance, online - learning. The idea of distance education traditionally included the separation of teacher and learner. With the development of the internet, such education is supported by the ICT. Rumble (1982), Farnes (1993), Mclsaac and Gunawardena (1993), Raggatt (1993), Garrison (1993) were among the first ones to analyse the strategic benefits of distance teaching.

As well as in Russian pedagogical literature, foreign researchers state there is a discrepancy in the usage of terms e-learning, distance learning, and distance teaching (King et al., 2001), while some authors suppose that these terms could be used interchangeably. This point of view was widely supported by the report issued by The Pew Learning and Technology Program in the USA: "The terms 'distance learning', 'distance education', 'distributed learning' and 'online learning' are used more or less interchangeably" Twigg, 2001: 4).

However, based on the abovementioned thesis, we cannot agree that these notions can be used interchangeably. We adhere to the position that 'distance education' and 'elearning' are "based on two different teaching/learning paradigms". Guri-Rosenblit (2005) highlights that 'distance education' is based on teaching large numbers of students by a handful of professors, most of whom do not communicate with the students at all, efficient 'e-learning' encourages direct interaction between a small number of students and expert teacher/s."

A very interesting question in this regard is the appearance due to COVID-19 Pandemic of a new term - 'emergency remote teaching'. According to the EDUCAUSE report by Brown (2020), who has been involved in the process of creating online courses for 24 years, states that there is a significant difference between "true online education and sudden." Emergency remote teaching is a temporary measure of delivering classes due to force-majeure circumstances.

Analyzing recent works of foreign authors concerning the sudden switch to remote learning, we can trace the tendency that universities with such experience of ICT learning found themselves more prepared. They were not starting from scratch with new and untested tech solutions (Czerniewicz, 2020). Others were underprepared and had to absorb new technologies. Among the most frequently met challenges, the authors define: incapacity to use ICT tools and applications, staff readiness, lack of students' motivation, student accessibility, technical difficulties, etc.

\section{Methodology}

This study employed an experimental research design. To specify the effect of integrated technologies on the students, we combined both qualitative and quantitative design: descriptive and statistical analyses (correlation analysis and T-test). Two groups of students (17 students) were taught with new technological instruments, and two groups of students (18 students) taught without such instruments. Overall, students of the first two groups achieved about $30 \%$ higher results than the other two groups' students.

The students were divided into four groups. Each group consisted of 9-10 students. The students were of the same level that had been identified previously at the moment of university entrance. The students had skyped sessions twice a week. Two groups

XLinguae, Volume 14 Issue 1, January 2021, ISSN 1337-8384, eISSN 2453-711X 
of students were taught with new tools. At the end of the semester, all four groups of students took online tests.

While remote teaching, we applied a flipped classroom strategy involving the students in the discussion and setting problems to be solved. To facilitate the process of studying doctrines, we applied an online mind map preparation at https://www.xmind.net. To improve legal vocabulary acquisition, we used a free online service Quizlet.

Collecting data included online tests and questionnaires. Four groups of students were asked to do an online test from quizlet.com, including legal problem tasks and vocabulary exercises. The first two groups of students were taught with the use of new tools. The average scores showed that these students achieved better results than the others. We applied correlation analysis to assess the correlation between the achievement of the first two groups of students with the integration of online teaching tools.

\section{Results and Discussion}

It should be noted that emergency remote teaching intercultural professional communication faced to some extent mentioned above challenges. Such an unforeseen development of distance learning courses turned out to be a far more laborious task. We take into consideration that teaching lawyers intercultural professional communication is intrinsically linked to the growing necessity for purposeful development of the intercultural legal space, the development of effective strategies for interaction in it, the development of the ability of lawyers to foresee future consequences of their actions and decisions in the areas of their professional activity.

Co-working in the classroom helps engage students in a broad scope of activities. The course aims to improve a foreign language as a means of professional communication, competently, applying the acquired skills to analyze foreign socio-cultural experience in all professional and research activities, and improving the intellectual and general cultural level.

With regard to vocabulary acquisition, students get familiarized with foreign legal systems, comparing them and analyzing different scholars' approaches. We are encouraged to facilitate our students' legal systems understanding, improve their linguistic performance, and socio-cultural background. The whole educational process rests on an active-oriented approach that means that the tasks are to reproduce situations from the real environment. Thus, students are treated as active participants and users of the language. (C. E. F. R., 2001). The students' tasks have, at its core, a legal problem that is to be solved. The educational procedure for teaching at nonlinguistics universities is described by Vonog and Yarotskaya (2018). Such an approach stimulates the ability to think clearly, critically, and coins to the widely expressed opinion that thought is inseparable from the way it is formed, meaning from language and speech. Consequently, psychologists and linguists conclude that the problem situation places paramount importance in the process of thinking and the process of speech production.

In spring 2020, students as part of the course "Intercultural professional communication" studied Criminal law. The course combines studying the doctrine that includes such legal issues as mens rea, actus reus, omission to act, causation etc. It envisages at understanding the foundation of criminal law and legal vocabulary acquisition. Due to the fact that we were to switch to remote learning, we had to find opportunities to meet the high-quality standard of education delivered at Moscow State Linguistic University. We should take into consideration that merely transferring educational content online (videos or lecture texts) will not have the same effect as in the classroom. 
In most cases, teaching is not only content. It is inextricably linked with the methods and ways of delivering this content to the students, social interaction in a group, and problem-solving itself. Consequently, we support the strategy of a flipped classroom dedicating the class period to enriching and deepening the concepts, involving the students in the discussion, and setting problems to be solved. At home, students are asked to watch videos based on the current legal issue and to come up with the questions while meeting on-line. The strategy that we applied for studying the doctrines is a mind map preparation that could be formed online at https://www.xmind.net. Mind maps are used by the students to study and analyze theoretical material, as shown in figure 1 below.

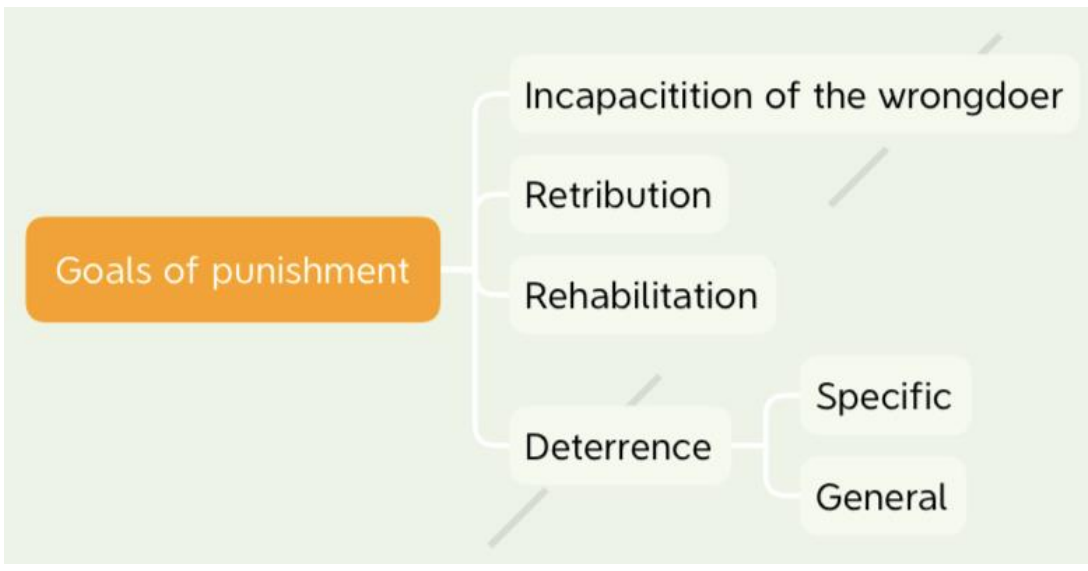

\section{Figure 1: Mind map example}

The other point necessary to mention is new vocabulary acquisition. It is proposed that to facilitate legal vocabulary acquisition during the COVID-19 Pandemic, we started using such apps as Quizlet. After discussing the target vocabulary, the students themselves upload the terms accompanied by definitions in the app. Quizlet is a free online service that allows students to learn new terms (when teaching a foreign language - new vocabulary) using special tools and educational games presented on this online platform. Students themselves or a teacher can create flashcards. A flashcard is the primary component of each training block that could include a term/word with a definition/translation, voice acting, and illustration. The training module consists of sets (sets) of cards on different topics. In order to create the modules, it is necessary to register and create an account. New words can be learned in five different learning modes and two games. The learning mode covers semanticization and memorization of vocabulary. The mode of cards touches upon the primary development of lexical units. The writing and spelling modes are aimed at building spelling skills. The types of tasks are shown in the figures below. (Figure 2) 


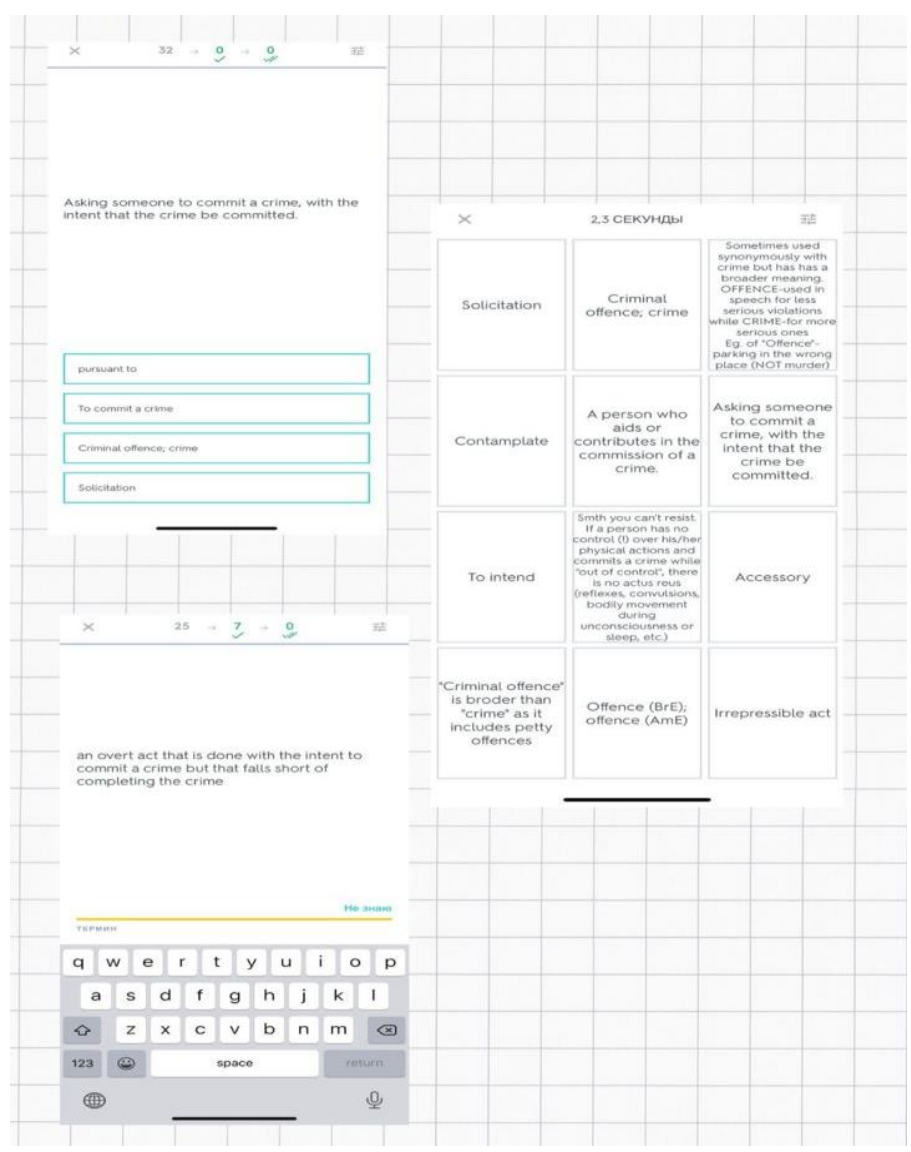

Figure 2: Quizlet tasks examples

Moreover, the use of such an app allows checking the knowledge of the vocabulary. While having an online class, a teacher could open the app and share the screen asking the students to define the terms provided.

According to Yarotskaya (2018), "the lawyers need to perceive sociocultural differences in the logic of lawyers' professional activities representing different legal systems." Nowadays, lawyers operate beyond national contexts. Subsequently, while teaching lawyers intercultural professional communication, we choose those tasks that simulate typical situations that lawyers may face in their professional employment. Novikova et al. (2018) coin to the idea that a foreign language can broaden students' outlook in the spheres of their interests. Nevertheless, we do not diminish the role of traditional tasks frequently carried out by law students (rendering and text analysis, translation, etc.). We will specify which contextual-based teaching methods are offered to the students during the course of intercultural professional communication and how their application has changed due to the COVID-19 Pandemic.

Talking about teaching methods, we mean educational problem-based situations and tasks, that as Verbitskii (1991) states, provide the transition from learning activity to quasi-professional and professional activities. There are those that enhance individualintellectual activity and complex ones that simultaneously realize intellectual and social activity. There are those that enhance individual-intellectual activity and 
complex ones that simultaneously realize intellectual and social activity. We are going to explore the first group. It includes various types of legal writing that fall into two broad categories:

- Legal analysis (memoranda and letters to clients);

- Persuasive legal writing (appellate briefs).

Writing clearly and concisely has always been defined as thinking clearly. It may seem incredible, but legal writing basics are as crucial for Anglo-Saxon lawyers as for Russian lawyers who are engaged in learning intercultural professional communication.

The course of legal writing is seen as one of the instruments of teaching law in the Anglo-Saxon legal system that is to prepare law students for a considerable burden of legal written work and to improve their writing skills. According to the director of Legal Writing University of New Hampshire School of Law, Vorenberg (2011), the first year Legal Writing course covers objective legal analysis and persuasive legal analysis that require specific skills development. Due to such an approach, after one year of studying legal writing students acquire a wide range of useful skills, including:

- reading and comprehension of legal documents;

- drafting a complete legal analysis;

- communicating the ideas clearly;

- improving overall literacy.

It respectively brings up the whole interesting idea that legal writing develops the whole personality that is eager to practice in the professional community. The critical point here is that we do not aim at teaching Russian lawyers how to make typical Anglo-Saxon legal documents in English. Our goal is broader - we teach how to analyse a stated problem in the most efficient and reasonable way. Russian law students get into legal cases synthesizing them in order to identify the critical facts of the case, form a rule with its subsequent explanation and application. The final stage of legal writing deals with a profound analysis of arguments and counterarguments in the outline.

Teaching legal writing in the classroom requires much attention from students and much enthusiasm from teachers. Legal writing professors state that "designing "mock" legal problems for first-year law students is a project unto itself" (Vorenberg, 2011). Teaching legal writing online turned out to be even more demanding and required much preparation from teachers. Unlike traditional legal writing classes that are separate, legal writing is entrenched into studying intercultural professional communication.

The students first study doctrinal issues, and then they are asked to deal with legal writing based upon the studied issues - for instance, a criminal issue involving actus reus. The issue is shown on the screen in the PowerPoint presentation. The issue may have about three cases, and students are asked to study the cases attentively, organize all the case details, and explain the legal issue provided. The form of legal writing could be a client letter that could be sent to the teacher via e-mail. Considering the fact that nowadays, a significant load of legal correspondence is being done through e-mail, it will be a real practical experience for future lawyers. Such types of e-mail are defined to be less formal and more comfortable to draft for those who have just started dealing with legal writing. Furthermore, such letters to a client can be answered by a teacher who will provide complete feedback. Legal correspondence, letters to a client are legal analysis.

When this competence is achieved, and law students have a solid foundation in the legal analysis, we move to persuasive legal writing.

According to Moylan and Brungess (2013), persuasive legal writing is a "written advocacy" that aims at "supporting your client's legal position." The approach is first

XLinguae, Volume 14 Issue 1, January 2021, ISSN 1337-8384, eISSN 2453-711X 
to study the case objectively and find counterarguments that will favor the client. For such an analysis, the students are asked to apply mind map software to compartmentalize the points.

The most difficult challenge that we have faced during the period of the remote COVID-19 learning is the lack of personal contact. The fact that students did not see each other in real life resulted in a sudden lack of motivation. After 40 minutes of classes, it turned out that their attention was less concentrated, and they seemed to be less involved. It was evident that we had to introduce more visual material that would keep the students motivated. On the other hand, remote learning opened access to ICT that had not been used before. Referring to the above-mentioned tasks of problemsolving and case-solving, we worked out QR-cards that had cases in a coded way. Coleman (2011) states that "QR-codes are two-dimensional images that, when scanned by a smartphone's camera, prompt the smartphone to open a web-page or display an image, video, or text." The case details are stated in the middle, and additional information is hidden in the labels, as shown in figure 3 below. These labels will send the students to the articles or similar cases to enrich their comprehension of the case. QR-codes are easily created with the help of QR-code generators. After that, it is necessary to copy the link from the address bar, and QRcode will be generated automatically in several seconds.

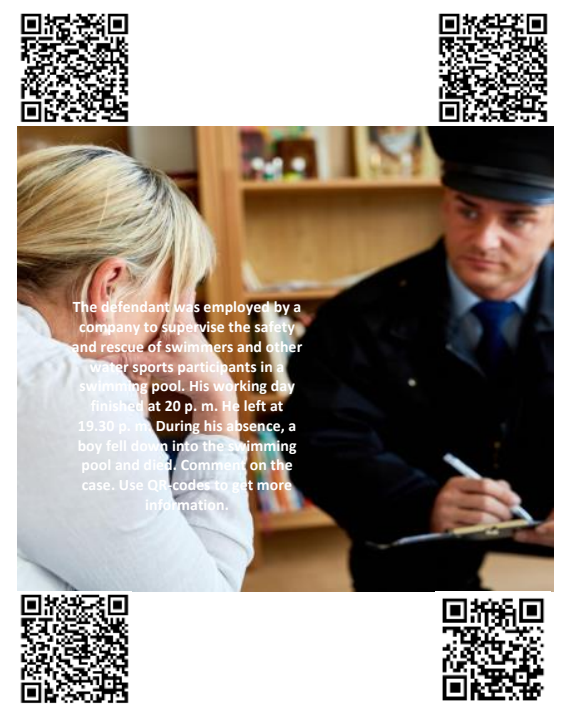

Figure 3: QR-code innovative tasks

\section{Conclusion}

The arrival of the coronavirus pandemic in Russia affected many sectors of the economy, the formats of interaction between people, business environment, work collectives. "The world after COVID-19 Pandemic would not be the same again" that is the phrase in common use. In spring 2020, we clearly understood that the educational system that worked cohesively preparing high-class specialists stopped operating. This dynamic system started changing hourly and daily. It is likely that in some areas of our life the nature of these changes will be smooth and gradual, and therefore little noticeable to the eye of an ordinary citizen. That is not to be said about the educational process. The challenges we met and the solutions provided showed the necessity of working hard to maintain a high level of education. 
Having analysed the current situation, it is possible to define the main problems that occurred with extreme remote teaching:

- lack of direct face-to-face communication between students and the teacher

- absence of distance learning experience

- insufficient development of information and communication infrastructure

- the problem of high-quality educational and material support for distance education

It should be noted that a significant drawback is the increasing energy and time consumption for course preparation. As it was mentioned above, it generally takes from 6-9 months to prepare a course-online. However, we had neither 6 nor 9 months. We were to think quickly and to come up with solutions that would keep students motivated and encouraged. Unfortunately, such solutions proved to be timeconsuming. According to the survey conducted by the Chartered College of Teaching (Müller, Goldenberg, 2020), the load on the teaching staff and students in the context of distance learning increased by $50-90 \%$.

Also prominent is the idea that not all the methods traditionally used in teaching could be transferred to remote teaching. We are in a constant search for such strategies that would enhance students involved in the process of studying intercultural professional communication. On the one hand, emergency remote teaching has revealed vulnerabilities. On the other hand, it has demonstrated teachers' and staff's organization skills, ability to adapt to new conditions, and creativity that helped to boost students' motivation in the educational process. Subsequently, university teachers will have to continually update and replenish their professional competencies to organize the educational process. COVID-19 pandemic has stimulated teachers to master new technologies. The idea of the university educational environment is the upbringing of an independent, critically thinking personality, ready to consciously build his own life, to raise his spiritual, moral, and professional level. We see the situation higher education faced as a good experience. Technological advances in the informatization of education open up new prospects for increasing the availability, efficiency, and quality of education.

\section{Bibliographic references}

ANDREEV, A. A. 1997. Introduction to distance learning. Distance learning: Tutorial // MOSCOW: Human., Center, Vlados, 210 p.

BROWN, M. 2020. Educause report. From Emergency Remote Teaching to Rigorous Online Learning. Available online: https://edtechmagazine.com/higher/article/2020/05/emergency-remote-teachingrigorous-online-learning-perfcon

CHERDAKLI, U. S. 2020. The specifics of work of pedagogical workers in the remote training system during the COVID-19 Pandemic. Available online: https://cyberleninka.ru/article/n/osobennosti-truda-pedagogieskih-rabotnikov-v-

sisteme-distantsionnogo-obucheniya-v-period-pandemii-covid-19

COLEMAN, J. 2011. QR Codes: What are they and why should you care? Kansas Library Association College and University Libraries Section Proceedings, vol. 1, n. 1, pp. 16-23. DOI: https://doi.org/10.4148/culs.v1i0.1355

COUNCIL OF EUROPE. 2001. The Common European framework of reference for languages: Learning, teaching and assessment. Cambridge: Cambridge University Press. Available online: http://www.coe.int/t/dgg/linguistic/source/manual/revisionproofread-final_en.pdf.

CZERNIEWICZ, L. 2020. What we learnt from "going online" during university shutdowns in South Africa. Available online: https://philonedtech.com/what-welearnt-from-going-online-during-university-shutdowns-in-south-africa/

XLinguae, Volume 14 Issue 1, January 2021, ISSN 1337-8384, eISSN 2453-711X 
FARNES, N. C. 1993. A distance education contribution to a social strategy to combat poverty: Open University Community Education courses in Glasgow. International Journal of Lifelong Education, vol.12, n. 3, pp. 191-204. ISSN: ISSN0260-1370

\section{FEDERAL LAW OF THE RUSSIAN FEDERATION ABOUT EDUCATION IN}

THE RUSSIAN FEDERATION. 2012. n. 273, Available online: http://www.consultant.ru/document/cons_doc_LAW_140174/

GARRISON, R. 1993. Quality and access in distance education: Theoretical considerations, in D. Keegan (Ed.) Theoretical Principles Of Distance Education. New York: Routledge, pp. 9-21. ISBN: 0-415-08942-5

GURI-ROSENBLIT, S. 2005. 'Distance education' and 'e-learning': Not the same thing. Springer. Higher education, vol. 49, n. 4, pp. 467-493. DOI: 10.1007/s10734004-0040-0

HODGES, C. - MOORE, S. - LOCKEE, B. - TRUST, T. - BOND, A. 2020. The difference between emergency remote teaching and online learning. Educause Review. Available online: https://er.educause.edu/articles/2020/3/the-differencebetween-emergency-remote-teaching-and-online-learning

KHUTORSKOI, A. V. 2000. On the development of distance education in Russia. Available online: https://cyberleninka.ru/article/n/o-razvitii-distantsionnogoobrazovaniya-v-rossii

KING, F. B. - YOUNG, M. F. - DRIVERE-RICHMOND, K. - SCHRADER, P. G. 2001. Defining Distance Learning and Distance Education. AACE Journal, vol. 9(1), pp. 1-14. Norfolk, VA: Association for the Advancement of Computing in Education (AACE). Available online: https://www.learntechlib.org/primary/p/17786/

KLARIN, M. V. 2016. Twenty-First Century Educational Theory and the Challenges of Modern Education: Appealing to the Heritage of the General Teaching Theory of the Secondary Educational Curriculum and the Learning Process. Russian Education \& Society, vol 58, n. 4, pp. 299-312. DOI: http://dx.doi.org/10.1080/10609393.2016.1250510

MCISAAC, M. S. - GUNAWARDENA, C. N. 1996. Distance Education. In D.H. Jonassen, ed. Handbook of research for educational communications and technology: a project of the Association for Educational Communications and Technology. New York: Simon \& Schuster Macmillan, pp. 403-437.

MCQUIRTER, R. - 2020. Lessons on change: shifting to online teaching during COVID-19. Brock Education Journal. A journal of educational research and practice, vol. 29 n. 2, pp. 47-51. Available online: https://journals.library.brocku.ca/brocked/index.php/home/article/view/840

MOYLAN, M-B. - BRUNGESS, A. L. 2013. Global Lawyering Skills. Persuasive legal writing. St. Paul: West Academic Publishing, 351 p. ISBN: 9780314277473

MULLER, L.M. - GOLDENBERG, G. 2020. Education in times of crisis: Teachers' views on distance learning and school reopening plans during COVID-19. Analysis of responses from an online survey and focus groups. Available online: https://my.chartered.college/wp-

content/uploads/2020/07/EducationInTimesOfCrisisII_20200708_final.pdf

NOVIKOVA, Y. B. - ALIPICHEV, A. Y. - KALUGINA, O. A. - ESMURZAEVA, Z. B. - GRIGORYEVA, S. G. 2018. Enhancement of socio-cultural and intercultural skills of EFL students by means of culture-related extra-curricular events. XLinguae, vol. 11, n. 2, pp. 206-217. DOI: 10.18355/XL.2018.11.02.16

POLAT, E. S. - BUKHARKINA, M.V. - MOISEEVA, A. E. 2008. New pedagogical and information technologies in the education system: studies. manual for students of higher educational institutions. Moscow: Publishing Center "Academy", 272 p. ISBN: 978-5-7695-4788-1.

RAFEEK, R. - SA, B. -HARNARAYAN, P. - FARNON, N. - SINGH, S. GIDDINGS, S. - REID, S. Rapid transition to online teaching during COVID 19: 
Students' and Teachers' Perceptions in a Pioneer Caribbean Dental School. Research Square. DOI: https://doi.org/10.21203/rs.3.rs-84862/v1

RAGGATT, P. 1993.Post-Fordismand distance education - a flexible strategy for change? Open Learning, vol. 8, pp. 21-31. DOI: https://doi.org/10.1080/0268051930080104

RUMBLE, G. 1982. The cost analysis of learning at a distance: Venezuela's Universidad Nacional Abierta. Distance Education, vol. 3, n. 1, pp. 116-140.

TANTSURA, T. A. 2020. The problem of students' motivation to learn a foreign language during the transition to a distance learning format. Available online: https://cyberleninka.ru/article/n/problema-motivatsii-studentov-k-izucheniyuinostrannogo-yazyka-v-period-perehoda-na-distantsionnyy-format-obucheniya TWIGG, C. 2001. Innovations in online learning: Moving beyond the no significant difference. Troy. NY: Rensselaer Polytechnic Institute, Center for Academic Transformation, Pew Learning \& Technology Program. Available online: https://files.eric.ed.gov/fulltext/ED470226.pdf

VERBITSKY, A. A. 1991. Active Teaching in College: Contextual Approach. Moscow: Vysshaya shkola, 204 p. ISBN 5-06-002079-7

VONOG, V. V. - YAROTSKAYA, L. V. 2018. Learning Individual's Development as Function of Productive Assessment. The Asian EFL Journal, vol. 20, n. 6, pp .429449. ISSN: 1738-1460. Available online: https://www.elejournals.com/asian-efljournal/the-asian-efl-journal-quarterly-june-2018/

VORENBERG, A. 2011. Strategies and Techniques for Teaching Legal Analysis and Writing. Wolters Kluwer Law \& Business, 62 p. Available online: https://ssrn.com/abstract=1988519

YAROTSAYA, L. V. 2018. Language pedagogy foundations of developing a contemporary lawyer's professional identity. Available online: https://cyberleninka.ru/article/n/lingvodidakticheskie-osnovy-formirovaniyaprofessionalnoy-lichnosti-sovremennogo-yurista

Words: 5377

Characters: 38147 (21,20 standard pages)

Senior Lecturer Darya V. Aleynikova, Phd

Department of Theory and Practice of Teaching Foreign Languages

Institute of Foreign Languages

People's Friendship University of Russia

Miklukho-Maklaya Str., 7

117198 Moscow

Russia

aleynikova-drvk@rudn.ru

Department of Linguistics and Professional Communication in the Field of Law

Institute of International Law and Justice

Moscow State Linguistic University

Ostozhenka Str., 38

119034 Moscow

Russia

festabene@mail.ru

XLinguae, Volume 14 Issue 1, January 2021, ISSN 1337-8384, eISSN 2453-711X 